sciendo Zagreb International Review of Economics \& Business, Vol. 24, No. 2, pp. 135-157, 2021

(C) 2021 Faculty of Economics and Business, University of Zagreb and De Gruyter Open

All rights reserved. Printed in Croatia

ISSN 1331-5609; UDC: $33+65$

DOI: $10.2478 /$ zireb-2021-0014

\title{
Corporate Social Responsibility and Organizational Performance: Mediating Role of Employee Job Satisfaction
}

\author{
Kong YuSheng* \\ Shaibu Ali* \\ Alhassan Alolo Abdul-Rasheed Akeji ${ }^{* *}$ \\ Abdul-Aziz Ibn Musah ** \\ Musah Ismaila*
}

Abstract: The study assesses the relationship between corporate social responsibility (CSR) and organizational performance of the companies listed on Ghana Stock Exchange (GSE). It further investigates the mediating effects of employee satisfaction on the relationship between CSR and OP. The survey data was collected from 246 responses, comprising junior and senior staff, senior level managers who are in charge of the day-to-day running of the companies and they are in the position to provide adequate and sufficient information with regards to the companies. A SmartPLS (version 3.2.3) was used to analyse the data. The findings of the study show that CSR activities significantly and positively influence organizational performance. This influence is found to be pronounced especially when CSR activities are deliberately exercised toward internal stakeholders. A positive relationship was found between CSR and ESAT, while ESAT also influence OP positively.

Keywords: Corporate Social Responsibility; Employee Job Satisfaction; Organisational Performance

JEL Classification: M14, M12, L25

\footnotetext{
* Kong YuSheng, Shaibu Ali and Musah Ismaila are at Jiangsu University ZHENJIANG, JIANGSU CHINA. Shaibu Ali is corresponding author.

*** Alhassan Alolo Abdul-Rasheed Akeji and Abdul-Aziz Ibn Musah are at Tamale Technical University- Ghana.
} 


\section{Introduction}

In recent time, the pressure imposed by employees, customers and the society has made the concept of CSR significant in the world of corporate bodies and institution across the globe (Fassin, 2009; Kassinis \& Vafeas, 2006). Over the years CSR and its influence on organizational performance (OP) have gained significant attention from scholars worldwide (López-Arceiz, Bellostas-Pérezgrueso, Moneva-Abadía, \& Rivera-Torres, 2018 Petrenko, Aime, Ridge, \& Hill, 2016; Miras Rodriguez, Carrasco Gallego, \&Escobar Perez, 2014).

However, plethora of studies investigating the direct relationship between CSR and organizational performance have provided mixed and diverging findings (Margolis \& Walsh, 2003; Mishra \& Suar, 2010; Oeyono, Samy, \& Bampton, 2011; Vogel, 2005.). While some studies reveal a positive relationship between CSR and OP (Abu Bakar \& Ameer, 2011; Van Beurden \& Gössling, 2008), others have opined that there is a negative relationship (Crisóstomo, Freire, \& Vasconcellos, 2011; Malcolm, Khadijah, \& Ahmad Marzuki, 2007). Some academic scholars have established no relation between the two constructs at all (Aupperle, Carroll, \& Hatfield, 1985). Other research works have also been extensively focused on CSR and customer satisfaction (Brown \& Dacin, 1997; Kang et al., 2010; Klein \& Dawar, 2004; Lee \& Park, 2009).

The main objective of CSR practices across the world today is to maximize the shareholders wealth and increase the value of the firm. However, recent studies have shown that apart from increasing the value of the firm (Leonardo, Rocco, Iftekhar \& Nada, 2012), CSR is a very important human resource management strategy and can be deployed to help increase employees loyalty to the organization. Prevailing literatures suggest that CSR activities today have moved from profit oriented strategy to employees' perspective (Rodrigo \& Arenas, 2008) where CSR is being categorized into internal and external, depending on which stakeholder they intend to satisfy. But to be specific, internal CSR activities entails employee's well-being and business ethics (Welford, 2004).

In a scholarly systematic literature review of Jamali and Karam (2018), they noted that 51 percent of research works paid attention on the organizational level, 13 percent on the institutional level, and 9 percent on the individual level, while the rest of the 27 percent left dealt with other level of analysis. Inferring from their research work, it is noticed that there is a dearth of scholarly attention on stakeholders' perspectives such as those of employees, customers, and hence, more stakeholder-focused research in the CSR discipline will be useful. Scholars such as (Chaudhary, 2018; Farooq, Payaud, Merunka, \& Valette-Florence,2014) have given insight into dimensions of CSR to include CSR towards the community, CSR towards the employee, and CSR towards customers. The present study does not decompose the multi-dimensional nature of CSR but rather paralyses the multi-dimensional nature of CSR into a mono dimensional construct. 
Also, Chiang (2010) asserted that investigations on CSR and Job satisfaction relationship remain scarce in scholarly literature. The few works done on CSR and job satisfaction suggest that, there is a positive relationship between the perception employees hold of their companies engagement in socially responsible activities and their level of satisfaction with works situation (Tziner, Oren, Bar, \& Kadosh, 2011), While other empirical studies showed that CSR enhances ESAT, since it has the potency to demonstrate social responsiveness by directly satisfying the employees' social requirement of the firms. CSR activity strengthens the relationship between the employees and the companies since employees benefit directly from the CSR activities.

The dearth of scholarly attention on the relationship between CSR and job satisfactions undermines the relatively importance of the employees in an organization (McWilliams \& Siegel, 2001). Job satisfactions play a pivotal role in every organizational setting by helping to create and sustain the firms value (Dawson \& Abbott, 2009). Previous studies have also proven theoretically and practically that ESAT and OP have significant positive relationship between them (Ellinger, Ellinger, Yang, \& Howton, 2002; Chan, Gee, \& Steiner, 2000; Latif et al., 2015; Mafini \& Pooe, 2013 Huselid, 1995; Koys, 2001).

Although earlier research has offered purposeful insights into the direct relationship between CSR and OP, several studies experience some significant limitations such as not considering the mediating variables which may have an effect on the relationship between corporate social responsibility and organizational Performance. A few studies have reported that CSR positively impacts organizational performance by enhancing employee satisfaction among the various stakeholders (Fombrun, 1996; Greening \& Turban,2000). However, such studies are unable to establish how employee satisfaction mediates the relationship between CSR and organizational performance. Thus the role of employee satisfaction as a mediator between CSR and OP also remains unattended, especially in the context of emerging economies firms where corporate social responsibility is needed most. This study argues that the relationship between CSR and a firm's performance diverges as per the firm's employee satisfaction. Therefore, employee satisfaction should be considered to be a mediator on the relationship between CSR and OP.

The study therefore seeks to scholarly enrich the debate of the relationship between CSR and OP by introducing an employee satisfaction to mediate the relationship between CSR and OP. This new construct may have effect on the relationship between CSR and OP in Ghanaian context especially on different organization in Ghana. Hence, this study tests the mediating effect of employee satisfaction on the relationship between CSR and OP.

However, employee satisfaction as never been tested empirically regarding the relationship between CSR and OP. Overwhelming justification therefore exist to conduct a study on the effect of employee satisfaction on the relationship between CSR-OP. The present study therefore, contributes to the CSR literature by empiri- 
cally analyzing CSR with relation to organizational performance, while deploying employee satisfaction to mediate the relationship between CSR and OP, specifically in the context of Ghanaian Stock-exchange firms.

\section{Materials and Methods}

\section{The stakeholder theory of CSR}

One of the early writers of the concept of stakeholder Freeman (1984) defines a stakeholder as "any group or individual who can affect or is affected by the attainment of the organisation's objectives". In enriching the association of stakeholder concept of CSR, other scholars (Garriga \& Melé, 2004; Pérez,López-Gutiérrez, García-De Los Salmones, \& San-Martín, 2019) explained that, the stakeholder theory of CSR states that people who are affected by (or affect) a company's plan programmes and actions are more likely to always identify themselves with having participated considerably in the firm and its corporate social performance. Stakeholders of the firm include stockholders, creditors, employees, customers, suppliers, public interest groups, and governmental bodies. Some past empirical research works have been conducted to find out best practices in corporate stakeholder relations (Bendheim,Waddock, \& Graves, 1998; Agle, Mitchell, \& Sonnefield, 1999;Mitchell, Agle, \& Wood, 1997; Berman et al., 1999; Rowley, 1997;Ogden \& Watson, 1999; Lee \& Heo, 2009).

Indeed, stake-holder theory relates to an organization's ability to make ethical assertions on anyone affected by its decisions, whether it is a customer, employee, supplier, or an individual from the community. Once an appropriate set of stakeholders of an organization has been identified, ethical implications result (Godos-Díez, Fernández-Gago,Cabeza-García, \& Martínez-Campillo, 2014). As organizations' major interest is the well-being of stakeholders, and therefore all efforts are directed towards exploiting every possible opportunity in the competitive business world to enhance performance.

The stakeholder theory stresses that, the central objective of an organisation is the maximization of profit, which translate into collective effect of a firm's actions on all stake-holders. Therefore, in line with the proposition of this stakeholder theory, it is contended that working towards socially responsible cooperation boosts an organization's overall performance.

\section{Relationship between CSR Activities and OP}

The effect of CSR on OP has been a topical issue for debate among researchers and scholars in the twenty first century. Many research works has been conducted to explore the effect of CSR activities on firm's performance .Different techniques and 
variety of methodologies have been used in different ways with different opinion and results. Findings of some research works revealed positive relationship between CSR and OP, others concluded that there is negative relationship, whereas some scholars point out neutrality. Emerging scholars like Lin Yang, \& Liou, (2009) and Saeidi \& Saaeidi (2015) have pointed out positive relationship between CSR and firm's performance. Research works conducted by Uadiale and Fegbemi (2012), Weshah et al. (2012) and Tsoutsoura (2004), show that there is a positive relationship between CSR and OP.

This means that organizations that consider CSR activities in their long term strategic plans will be seen as a socially responsible firm, and will therefore appear to be responsible before its stakeholders.

On the other hand, scholars like Yang Lin and chang (2010) holding a differing view, from their study, they found out that, CSR activities have negative impact on OP. This is in line with Friedman (1970)'s work and other neoclassical economists of the time. They suggested that CSR activities come with a lot of cost and few economic benefit, the numerous cost outweigh the benefit which end up reducing the profit and lower the shareholders wealth (Waddock \& Graves, 1997). This suggested that, organization's idle funds that contribute to CSR activities have negative impact on OP. Organizations must be compelled to put the idle funds in a productive project or investment that will yield more profit instead of embarking on CSR activities. Yan Lin and Chang (2010) further argue that, the main objective of every firm is to make profit for the shareholders and not for the whole society; hence they are not liable to use any of the idle funds for the development of the society. They suggested that by carrying out CSR activities, companies are weak in terms of their financial strength.

Khanifar et al. (2012) and Orlitzky et al. (2003) have also contributed to the differing arguments on the relationship between CSR and OP, by revealing that, they found no relationship between CSR and financial performance. This was pointed out from analysis conducted from previous empirical research works. Nevertheless, recent scholars like (Maron, 2006; Wu, 2006; Rodgers et al., 2013; Gallardo-Vazquez and Sanchez - Hernandez, 2014a) have stressed that, there is a positive relationship between CSR activities and OP. In this view, the following hypothesis is proposed on the relationship between CSR and OP:

H1: Perceived CSR activities have a positive effect on OP

\section{CSR Activities and its relationship with ESAT}

Meyer and Allen (1997) did extensive works on the theory of organizational commitment, and explained that, employees who are satisfied are with their jobs tend to be more committed to their work and have the possibility of remaining in the organization than those who are less committed. 
Some scholarly studies suggested that, ethic code, ethic training and perceived CSR do have positive relationship with ESAT. This is in line with past suggestion that organizational ethics related to employees have positive response to work and organization (Koh \&Boo, 2001; Valentine \& Barnett, 2003). Research conducted on 850 companies in the United States from the period of 1999 to 2007 suggested that, there is a positive and significant relationship between CSR activities and job satisfaction, Blazovich \& Smith, (2010) added that, there is a positive relationship between corporate citizenship and job satisfaction. They further explained that, good moral corporate behaviour does have impact on the value of firm's share. Similar works from Joshi et al., (2010) show that moral corporate behaviour does have positive and strong relationship with job satisfaction. They again have positive impact on the profit of the firm. It further explained that profit making expand and make firms grow, which at the end of the day all stakeholders do benefit from it.

Furthermore, some research works explain that CSR is a voluntary activity and considered social activities rather than profit oriented activities, and that has the potential to elicit attribution of morality, which strengthens the social ties between the employees and the organization. CSR activities of firms increase identification, commitment, good organizational citizenship behaviour and meaningfulness (Aguilera, Rupp, Williams, \& Ganapathi, 2007).

CSR activities can positively boost up the perception of employees towards their firms (Raihan \&Karim ( 2017), Chiang (2010) attested to the fact that Job satisfaction, customer understanding and trust depend on pragmatic and importance of CSR activities of the organization. Many studies on CSR strategies of companies have significant impact on employee's attitude and behaviour (Barnett, 2007). When companies embark on CSR activities, it create significant impact on employees commitment, satisfaction, trust, loyalty, self-image, which helps employees to identify themselves with certain group (organization), and fulfills the need for belonging and membership (Skudiene \& Auruskevicience, 2012). According to Garvin and Maynard (1975), they suggested that, the degree at which organization fulfills it CSR obligation creates significant relationship between CSR and job satisfaction, and that makes the employees to be satisfied and feels part of the organization.

Recent literatures explained that, employees expectations of CSR activities by their companies should provide them Job security, rewards, good recognition, personal development, work-life-balance, health and safety and good retirement benefit (Maignan et al., 2005). This explains that, when an employee is been assured of what Maignan et al., (2005) identified a as part of their internal CSR activities benefit, there is the likelihood that, the employee may be satisfied with his job, thereby staying in the company till retirement (Valentine \& Fleischman, 2007; Koh \& Boo 2001; Brammer et al 2007). Based on the above assertion, we hypothesize that:

H2: CSR Activities have direct positive relation with Employees Job satisfaction 


\section{Relationship between ESAT and OP}

ESAT plays a key role when it comes to OP. It is in the best interest of the organization to know how to retain their employees by making them satisfied and motivated in order to achieve an extraordinary outcome. Previous research works on ESAT and OP have suggested that, there is an existence of positive correlation between job satisfaction and OP (Miah, 2018; Mafini \& Pooe, 2013; Muhammad et. al 2013; Goslin, 2005; Harter, Schmidt, \& Keyes, 2003; Judge, Thoresen, Bono, \& Patton, 2001; Wright \& Cropanzano, 2000). Other authors of research works also found positive correlation between ESAT and OP (Chan et al., 2000; Chandrasekar, 2011; Ellinger et al., 2002; Harter, Schmidt, \& Hayes, 2002; Huselid, 1995; Koys, 2001; Schneider, Hanges, Smith, \& Salvaggio, 2003; Zohir, 2007). Recent authors also suggested a positive correlation between ESAT and OP (Huselid, 1995; Koys, 2001; Ellinger, Ellinger, Yang, \& Howton, 2002; Latif et al., 2015; Mafini \& Pooe, 2013; Chan, Gee, \& Steiner, 2000).

Researchers like OStroff (1992) suggested that employees who are more satisfied with their jobs tend to be more effective to their organizations than those who are dissatisfied. Evans and Jack (2003) also suggested in their works that, ESAT has positive impact on organizations market performance. Schneider et al (2003) also added that, Return on Asset (ROA), higher Earnings per Shares (EPS) were having positive relationship with higher job satisfaction. Based on the above assertion, the following hypothesis will be proposed;

H3: There is a positive relationship between ESAT and OP.

\section{The mediation effect of ESAT on the relationship between CSR and OP.}

Over the years CSR and its influence on organizational performance (OP) have gained significant attention from scholars worldwide (López-Arceiz, Bellostas-Pérezgrueso, Moneva-Abadía, \& Rivera-Torres, 2018 Petrenko, Aime, Ridge, \& Hill, 2016; Miras Rodriguez, Carrasco Gallego, \&Escobar Perez, 2014). Blazovich \& Smith, (2010) also added that, there is a positive relationship between corporate citizenship and job satisfaction. They explained that, good moral corporate behaviour does have impact on the value of firm's share. Similar works from Joshi et al., (2010) show that moral corporate behaviour does have positive and strong relationship with job satisfaction. They again have positive impact on the profit of the firm. It further explained that profit making expand and make firms grow, which at the end of the day all stakeholders do benefit from it. According to Garvin and Maynard (1975), they suggested that, the degree at which organization fulfills it CSR obligation creates significant relationship between CSR and job satisfaction, and that makes the employees to be satisfied and feels part of the organization.

On the basis of that, we hypothesize that:

H4: ESAT mediates the relationship between CSR and OP. 
Figure 1: Conceptual model and hypotheses of the study

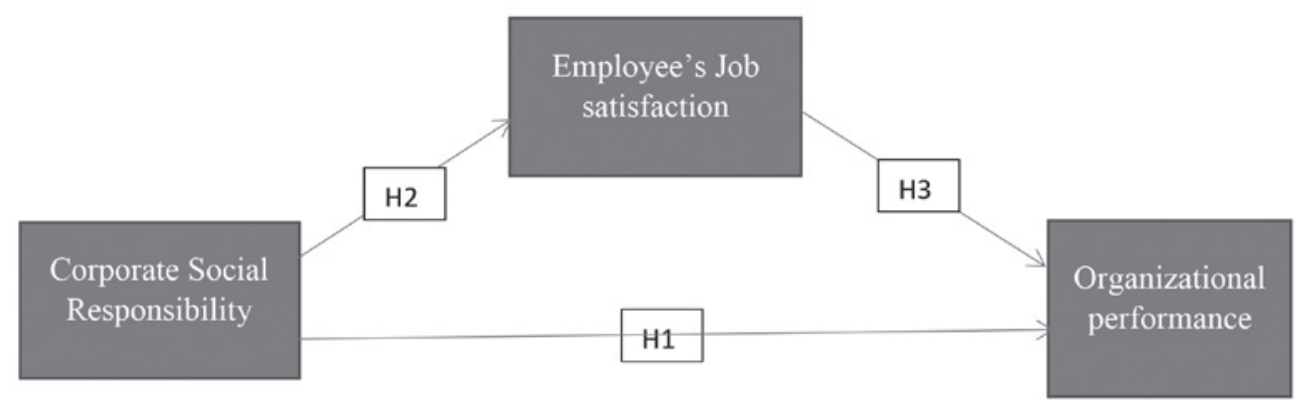

\section{Methodology}

The conceptual model Figure- 1 and the related hypotheses to the study were drawn from the literature above. The purpose of this paper is to investigate the mediating role of ESAT on the relationship between CSR and OP in some organizations in Ghana. A convenient sampling method was used to select respondent (employees) from all the companies listed on Ghana Stock Exchange (GSE). The data were collected from April 2019 to June 2019. Respondents sampled were 400, and only 246 responses out of the total administered questionnaires were retrieved. The composition of the sample is made up of junior and senior staff, senior level managers who are in charge of the day-to-day running of the companies and they are in the position to provide adequate and sufficient information with regards to the companies.

To ensure the instrument's validity, each construct was measured using multiple items, and each item was adapted from prior research but modified to fit our context of study. Two sections made up the survey questionnaire. The first gathered demographic data about the subject. Gender, age, education level, industry, ownership and number of employees were all assessed as demographic variables.

The second section of the questionnaire entailed closed ended questions for the constructs. Items for each of these constructs are measured using five-point Likert scales with response options ranging from strongly disagree (1) to neutral (3) to strongly agree (5). Scales for the study were adapted from Swaen and Chumpitaz (2008) to measure CSR. The measuring Scale for ESAT were adapted from Netemeyer et al. (1997) and Hartline and Ferrell (1996), whiles the measuring scale OP were adapted from Maignan et al. (1999, 2001). 


\section{Results and Discussions}

\section{Confirmatory Factor Analysis (CFA)}

Harmann's Single -Factor test was employed for the study to check the common method variance and exploratory factor analysis (EFA) was used to facilitate the test. Initially, 21 construct were keyed in but 7 were later removed leaving 14 items .This account for about $73.90 \%$ of the variance in the sample (See Table-1).

Table 1: KMO and Bartlett's Test

\begin{tabular}{|l|l|r|}
\hline \multicolumn{2}{|l|}{ Kaiser-Meyer-Olkin Measure of Sampling Adequacy. } & .739 \\
\hline \multirow{3}{*}{ Bartlett's Test of Sphericity } & Approx. Chi-Square & 608.937 \\
\cline { 2 - 3 } & df & 36 \\
\cline { 2 - 3 } & Sig. & .000 \\
\hline
\end{tabular}

\section{Reliability and Validity of Scales}

The convergent and discriminant validity of the data were measured through confirmatory factor analysis using statistical package for social sciences (SPSS V.22). Exploratory Factor Analysis was employed to measure the 13 construct. Bartlett's Test of Sphericity was adopted for the measurement of construct validity whiles the Kaiser-Meyer-Olkin (KMO) was employed for the measurement of Sampling Adequacy of individual variables. Kaiser-Meyer-Olkin (KMO) as explained by özdamar (2017) in his work should be 0.6 or even more for the factor analysis. From the results above, Bartlett's Test of Sphericity and Kaiser-Meyer-Olkin (KMO) depicts that both are significant and suitable for the factor analysis (See Table-1). Cumulative variance from the table shows $73.90 \%$, which indeed exceeds the minimum acceptance level of 60\% (özdamar, 2017), The Bartlett's Test of Sphericity from the table shows the correlation between the variables, its shows 608.937 which is sufficient, and significant $(\mathrm{P}>0.000)$. Whiles the factor loadings of all the constructs exceeded 0.5 (Hair, Ringle, \& Sarstedt, 2011; Ringle, Wende, \&Becker, 2015).The above values shows that, there is convergent and discriminant validity (See Table-1).

\section{Demographics characteristics of respondents}

This section presents the demographic data on respondents including ownership, gender, number of employees, age, level of education, industry and their results (See Table-2). 
Table 2: Demographics of respondents

\begin{tabular}{|c|c|c|c|}
\hline Variable & Category & Frequency & Percentage $\%$ \\
\hline \multirow{2}{*}{ Gender } & Male & 158 & 61 \\
\hline & Female & 102 & 39 \\
\hline \multirow{4}{*}{ Age (years) } & $18-25$ & 54 & 22 \\
\hline & $26-33$ & 97 & 39.4 \\
\hline & $34-41$ & 68 & 27.6 \\
\hline & $42+$ & 27 & 11.0 \\
\hline \multirow{6}{*}{ Level of education } & Basic level & 7 & 2.8 \\
\hline & High Sch. & 35 & 14.2 \\
\hline & Diploma & 41 & 16.7 \\
\hline & Undergraduate & 62 & 25.2 \\
\hline & Graduate & 88 & 35.8 \\
\hline & Others & 13 & 5.3 \\
\hline \multirow{8}{*}{ Industry } & Banking \& Finance & 68 & 27.6 \\
\hline & Manufacturing & 51 & 20.7 \\
\hline & Trading & 39 & 15.9 \\
\hline & Beverage \& Food Manuf. & 15 & 6.1 \\
\hline & Telecommunication & 9 & 3.7 \\
\hline & Chemical \& Pharm. & 15 & 6.1 \\
\hline & Diversified & 6 & 2.4 \\
\hline & Others & 43 & 17.5 \\
\hline \multirow{3}{*}{ Ownership } & Private Limited & 180 & 73.2 \\
\hline & Public Limited & 36 & 14.6 \\
\hline & Government & 30 & 12.2 \\
\hline \multirow{5}{*}{ No. of Employees } & Less than 1000 & 180 & 73.2 \\
\hline & $1000-5000$ & 50 & 20.3 \\
\hline & $5000-10000$ & 11 & 4.5 \\
\hline & $10000-20000$ & 3 & 1.2 \\
\hline & More than 20000 & 2 & 0.8 \\
\hline
\end{tabular}

The above Table 2 shows that, in terms of gender $61 \%$ of the respondent were males; and 39\% were females. $22 \%$ of the respondent were between the age of 18 and 25 years; $39.4 \%$ were between the age of 26 and 33 years; $27.6 \%$ of the respondent were between the age of 34 and 41 years; and $11.0 \%$ were above 42 years of age. With respect to education, about $2.8 \%$ of the respondent have Basic education level; $14.2 \%$ of the respondent have High education level; $16.7 \%$ of the respondent have Diploma education level; $25.2 \%$ of the respondent have First degree; $35.8 \%$ of the respondent have Post Graduate degree; $5.3 \%$ of the respondent have other level of education. About 27.5\% of the respondent comes from the Banking and Finance industry; 20.7\% 
of the respondent were from the Manufacturing industry; $15.9 \%$ of the respondent were from the Trading industry ; $6.1 \%$ of the respondent were from the Beverage and Food Manufacturing industry ;3.7\% of the respondent were from the Telecommunication industry, $6.1 \%$ of the respondent were from the Chemical and pharmaceutical industry, $2.4 \%$ of the respondent were from diversified industry whiles 17.5 are those from other industries. In terms of Ownership, $73.2 \%$ of the respondent were from the Private limited companies; $14.6 \%$ of the respondent were from the Public limited companies whiles $12.2 \%$ of the respondent were from the Government Sector. About $73.2 \%$ of the respondent were from companies that has less than 1000 employees; $20.3 \%$ of the respondent were from companies that has between 1000-5000 employees; 4.5 of the respondent were from companies that has between 5000-10000 employees; $1.2 \%$ of the respondent were from companies that has between 10000 20000 employees whiles $0.8 \%$ of the respondent were from companies that has employees above 20000.

\section{Measurement model reliability and validity}

Measuring the extent of the internal consistency, construct reliability was used. This assessment is done through an item loading with acceptable value of 0.70 and considering Cronbach's Alpha level of acceptable region of 0.70 (Ringle et al., 2015; Hair et al, 2011, p.144). The construct in the table shows that, the item loadings are all higher than the recommended 0.70 (See Table-3).

Table 3: Item loading and construct reliability

\begin{tabular}{|c|c|c|c|c|c|}
\hline ITEMS & FL & $\mathrm{CA}$ & rho_A & CR & AVE \\
\hline CSR 1 & 0.837 & 0.929 & 0.931 & 0.994 & 0.737 \\
\hline CSR 2 & 0.851 & & & & \\
\hline CSR 3 & 0.871 & & & & \\
\hline CSR 4 & 0.862 & & & & \\
\hline CSR 5 & 0.864 & 0.834 & 0.968 & 0.881 & 0.651 \\
\hline CSR 6 & 0.864 & & & & \\
\hline ESAT 1 & 0.804 & & & & \\
\hline ESAT 2 & 0.758 & & & & \\
\hline ESAT 3 & 0.773 & & & & \\
\hline ESAT 4 & 0.886 & & & & \\
\hline OP 1 & 0.887 & 0.904 & 0.904 & 0.933 & 0.776 \\
\hline OP 2 & 0.887 & & & & \\
\hline OP 3 & 0.878 & & & & \\
\hline OP4 & 0.871 & & & & \\
\hline
\end{tabular}

Notes: OP - Organizational Performance, CSR - Corporate Social Responsibility, ESAT - Employee's Job Satisfaction, FL - Item Loadings, CA - Cronbach's Alpha, CR - Composite Reliability, AVE - Average Variance Extracted 
However, the above Table-3, shows that all the variables presented are above the minimum Cronbach's Alpha of 0.70, which indicates that, each construct for the measurement is highly reliable. Construct validity, according to Fornell \& Larcker (1981a) is assessing the degree to which a measurement represents and logically connects the observed phenomenon to the construct through the fundamental theory. It is assessed through convergent validity and discriminant validity (Ringle et al., 2015). The AVEs and the CR has meet the minimum of 0.5 and 0.70 respectively (Fornell \& Larcker, 1981; Ringle et al., 2015).This depicts that the convergent validity is clearly adequate.

Table 4: Discriminant Validity

\begin{tabular}{|l|c|c|c|}
\hline & CSR & ESAT & OP \\
\hline CSR & $\mathbf{0 . 8 5 8}$ & & \\
\hline ESAT & $\mathbf{0 . 0 9 3}$ & $\mathbf{0 . 8 0 7}$ & 0.881 \\
\hline OP & $\mathbf{0 . 9 8 3}$ & 0.098 & \\
\hline
\end{tabular}

Discriminant analysis according to Messick (1988), requires a factor to correlate higher than with any other construct on its scale. All the factor loaded higher than any other factor on their scales. CSR on its scale had a value of about $(0.85)$ which is higher than any other construct on that scale. ESAT had a value of $(0.80)$ and OP is (0.88) which are all higher than any other factors on their scales.

\section{Findings of Structural Model}

Figure 2: Structural Model of the direct paths with coefficients

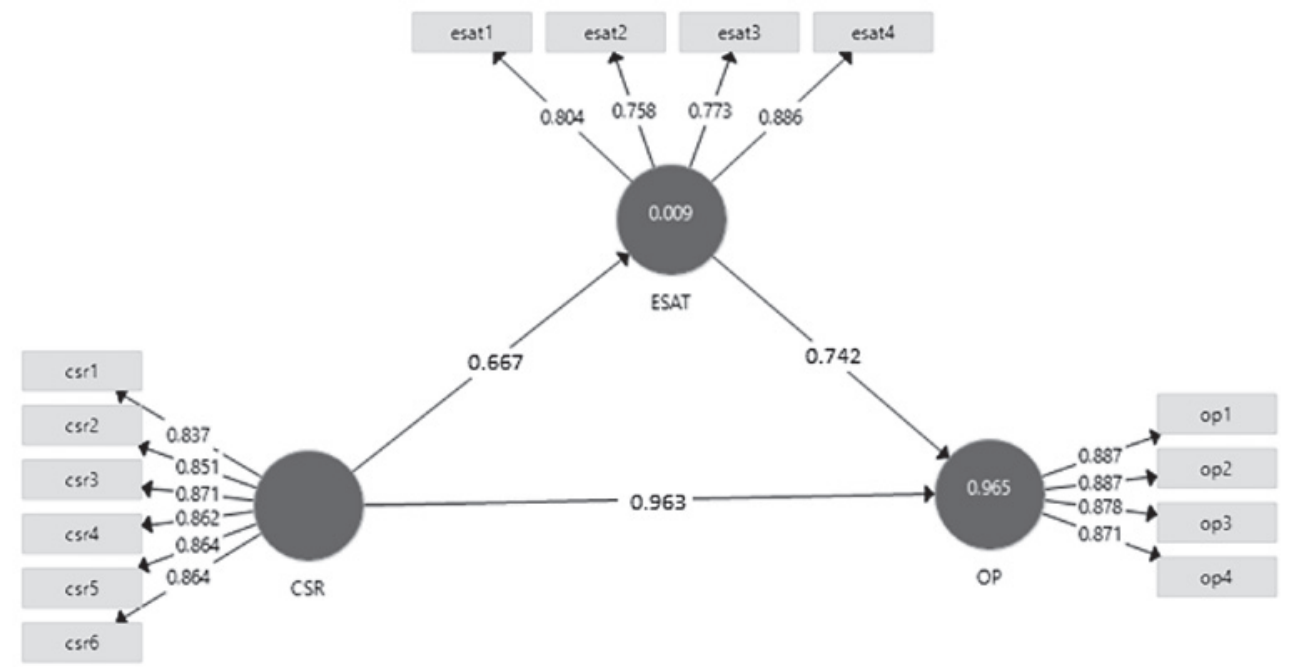


The structural model assessment was done through the regression weight, p-values, t-values for significance of t-statistics (Chin, 2010; Ringle et al., 2015). The outcome of structural model for testing the research hypotheses are depicted in Table- 5 below.

\section{Hypothesis test}

Test of hypothesis was carried out to examine the mediating effect of ESAT on the relationship between CSR Activities and OP using SmartPLS Software. Two models were tested (See Table 5). The first model that we tested was on the relationship between CSR Activities and OP. CSR activities had a significant and positive effect on OP. OP $(\beta=0.963 ; t=60.187 ; p<0.000)$. This led to the acceptance of H1. This means that CSR activities have greater positive effect on OP. Also, when CSR activities increase by $1 \%$, OP increases by $96.3 \%$. Thus when an organization embarks on CSR activities, it creates a positive image for the company and as well in the minds of the investors to invest more in that company. Employees will feel happy by enjoying the intrinsic value of it and customers will be served better, so that they can buy more from the company. This positive image alone creates a lot of big opportunity to the company in terms of sales and more investors to come in. This finding supports earlier findings by (Gallardo-Vázquez \& Sanchez-Hernandez, 2014; Larrán Jorge et al., 2015).

However, we tested the relationship between CSR activities and ESAT. CSR activities had a significant and positive effect on ESAT. ESAT $(\beta=0.667 ; \mathrm{t}=14.822$; $\mathrm{p}<0.011)$. And this led to the acceptance of $\mathrm{H} 2$. What this means is that, when CSR activities increases by $1 \%$, ESAT increase by $66.7 \%$. Thus Organizations that carryout CSR activities do achieve their organizational objective most of the time. The fact is ,many workers do associate themselves with institutions that carryout CSR activities (Skudiene \& Auruskeviciene, 2012). This is because many of them sees CSR as a charity activities thus giving back to the community .That one alone gives them some form of motivation to work with the institution. For instance is the case of MTN Ghana, where employee's feels motivated to be with the company because of the CSR activities they carry on across Ghana. For instance, MTN Ghana invested in about 142 major project in the area of education, health and economic empowerment which impacted in the lives of about four million Ghanaians (www.myjoyonline.com). For that matter employees of such companies find it difficult to switch to different company because, they feel motivated to be part of this company as a result of the good CSR programme the company carryout in their communities and the country as a whole. This is in line with the report of https://ca.indeed.com on employee happiness with a company with regards to the project and programmes the company do carry out and the earlier findings of (Aguilera et al., 2007; Barnett, 2007; Chiang, 2010).

We tested the relationship between ESAT on OP in the final model, ESAT had a significant and positive effect on OP. OP $(\beta=0.742 ; t=57.077 ; p<0.000)$. And this led to the acceptance of $\mathrm{H} 3$. The Beta scores mean that, when ESAT increases by $1 \%$, 
OP increase by $74.2 \%$. This means that when an employee is treated well, motivated by the organization, they tend to be happy and be satisfied. Employees who are happy at the workplace tend to show better attitude to the job they do when an organization takes into consideration of employee's psychological contract fulfillment such as good salary, health care benefit and so on. This employees tend to give out their best in terms of their job performance, which will later translate into more sales to the company and subsequently lead to profitability to the company. This finding supports earlier findings by (Miah, 2018; Mafini \& Pooe, 2013; Muhammad et. al 2013; Goslin, 2005).

Table 5: Hypothesis Test

\begin{tabular}{|l|c|c|c|c|c|c|c|}
\hline Paths & beta & $\begin{array}{c}\text { Standard } \\
\text { Deviation }\end{array}$ & t-values & p-Values & \multicolumn{2}{|c|}{ 95\% CI } & Decision \\
\hline $\mathrm{CSR} \rightarrow \mathrm{OP}$ & 0.963 & 0.016 & 60.187 & 0.000 & 0.941 & 0.970 & Accepted \\
\hline $\mathrm{CSR} \rightarrow \mathrm{ESAT}$ & 0.667 & 0.045 & 14.822 & 0.011 & 0.632 & 0.693 & Accepted \\
\hline $\mathrm{ESAT} \rightarrow \mathrm{OP}$ & 0.742 & 0.013 & 57.077 & 0.000 & 0.725 & 0.751 & Accepted \\
\hline
\end{tabular}

Note: * significant at 0.05 , *** significant at 0.001 ; CSR - Corporate social responsibility, - ESAT - Employees Job satisfaction, OP - OP.

\section{Mediation Analysis}

In carrying out mediation test, there is the need for the establishment of mediation effect. Baron and Kenny (1986) mediation guideline were used in checking all significant parameters as well as fulfilling the full and partial mediation conditions. Estimation of all regression analysis in the study were carried out. ESAT which is the first mediating variable was regressed on CSR (independent variable) and it showed that there is a significant positive effect (CSR $\rightarrow$ ESAT, $\beta=0.667, p=0.000$ ). Secondly, OP (dependent variable) was regressed on CSR (independent variable) and this showed that there is a significant positive effect. (CSR $\rightarrow$ OP, $\beta=0.968, p=0.000$ ), Thirdly, OP (dependent variable) was regressed on CSR (independent variable) and ESAT (ESAT) (mediator) and the effect was significant. (CSR $\rightarrow$ ESAT $\rightarrow$ OP, $\beta=0.963$, $\mathrm{p}=0.000$ ), lastly OP (dependent variable) was regressed on ESAT (independent vari$\mathrm{able}$ ) and this showed a significant effect (ESAT $\rightarrow \mathrm{OP}, \beta=0.742, \mathrm{p}=0.000$ ). The Table 7 below displays the outcome of the regressions. The condition guideline of assumption by Baron and Kenny (1986) was fulfilled by considering the three relationships to be significant, then mediation testing would be possible. As seen in Table 6 , all the path are significant which shows that there is a mediation. 
Table 6: Mediation Analysis Table

\begin{tabular}{|l|c|c|c|c|c|c|}
\hline Paths & beta & $\begin{array}{c}\text { Standard } \\
\text { Deviation }\end{array}$ & t-values & p-Values & \multicolumn{2}{|c|}{ 95\% CI } \\
\hline $\mathrm{CSR} \rightarrow$ ESAT & 0.667 & 0.045 & 14.822 & 0.011 & 0.632 & 0.693 \\
\hline $\mathrm{CSR} \rightarrow$ OP(without mediator) & 0.968 & 0.015 & 64.533 & 0.000 & 0.957 & 0.974 \\
\hline $\mathrm{CSR} \rightarrow \mathrm{OP}($ with mediator) & 0.963 & 0.016 & 60.187 & 0.000 & 0.941 & 0.970 \\
\hline $\mathrm{ESAT} \rightarrow \mathrm{OP}$ & 0.742 & 0.013 & 57.077 & 0.000 & 0.725 & 0.751 \\
\hline $\mathrm{CSR} \rightarrow \mathrm{ESAT} \rightarrow \mathrm{OP}($ specific indirect) & 0.495 & 0.022 & 22.500 & 0.009 & 0.481 & 0.510 \\
\hline
\end{tabular}

Note: * significant at 0.05 , *** significant at 0.001 ; CSR - Corporate social responsibility, - ESAT - Employees Job satisfaction, OP - Organizational Performance.

With respect to this type of relationship, if CSR on OP is less in the third model than in the second model, then the mediation is said to be partial. Full mediation holds if CSR has no effect when the ESAT is controlled. But in this scenario the third model was significant but less $(\beta=0.963)$ than the second model $(\beta=0.968)$ which shows that there is partial mediation. Even though the t-values in the third model and in the second models are significant, the significant level for model two (p-value = $0.000)$ was stronger than that of model $3(\mathrm{p}$-value $=0.000)$. This indicates that there is partial mediation.

After determining that Employees Job Satisfaction by an organization partially mediates the relationship between CSR and OP, a logical analysis was applied to the structural model to provide a broad representation of $\mathrm{H} 2$ and $\mathrm{H} 3$. First, the path coefficients for the relationships between CSR and the OP was tested. The outcome of CSR on OP was positive and statistically significant $(\beta=0.963$, $p$-value $=0.000)$ with a $\mathrm{t}$-value $>$ (60.187) which is $>2$.

Second was the inclusion of the mediating variable. The second and last objectives of this paper were to find the mediating role of Employees Job Satisfaction and the relationship between Employees Job Satisfaction and OP. The result shows that Employees Job Satisfaction has partial mediation, the relationship between CSR activities and OP as both the indirect effect with mediator (CSR $\rightarrow$ CSAT $\rightarrow$ OP, path 1: $\beta=0.963, p=0.000$; path $2: \beta=0.742, p=0.000$ ) and the direct effect without mediator $(\mathrm{CSR} \rightarrow \mathrm{OP}, \beta=0.968, \mathrm{p}=0.000)$ were significant. The results implied that CSR influences OP even without ESAT. However, ESAT has positive significant relationship between CSR and OP since it has positive relationship with OP $(\beta=0.963$, $\mathrm{p}=0.000$ ). This provides support for $\mathrm{H} 2$ and $\mathrm{H} 3$. Table- 6 shows a summary of the mediation test.

Again, establishing the mediation effect, the variation accounted for (VAF) condition by Hair et al., (2013, P.224) will be considered. So to calculate the VAF; 
Figure 3: Mediation Analysis

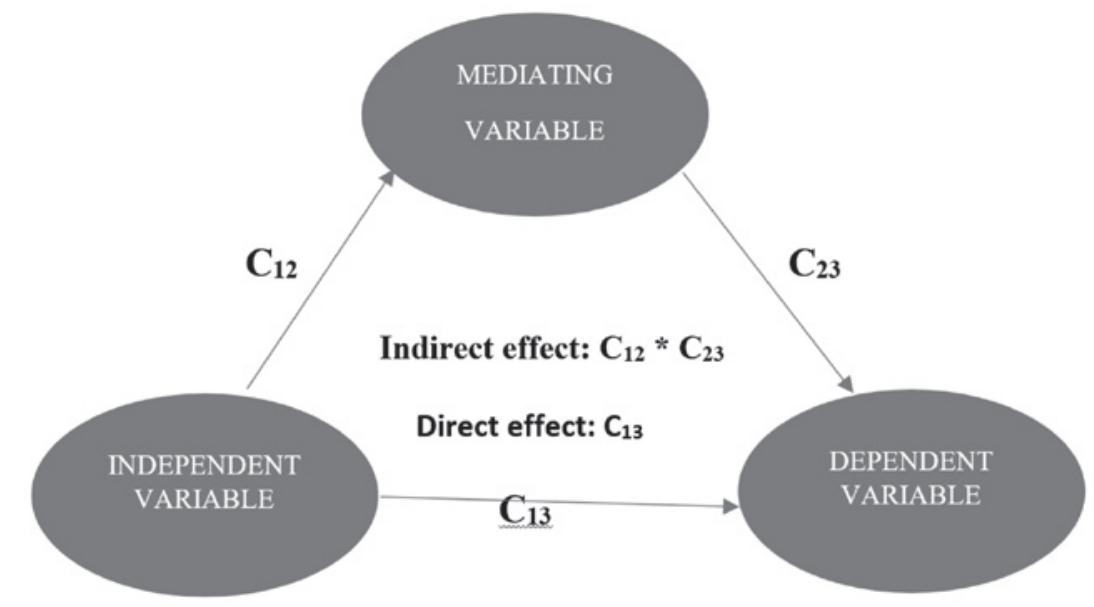

$\mathrm{VAF}=(\mathrm{C} 12 * \mathrm{C} 23) /(\mathrm{C} 13+\mathrm{C} 12 * \mathrm{C} 23)$.

i) If $0<\mathrm{VAF}<0.20$, then No Mediation.

ii) If $0.20<\mathrm{VAF}<0.80$, then Partial Mediation.

iii) If VAF $>0.80$, then Full Mediation.

Therefore:

Total effect $=0.963+0.495=\mathbf{1 . 4 5 8}$

Indirect effect $=\mathbf{0 . 4 9 5}$

Table 7: Mediation Analysis: ESAT as Mediator

\begin{tabular}{|c|c|c|c|c|c|}
\hline Independent Variable & Direct Effect & Indirect Effect & Total Effect & VAF Range & Mediation \\
\hline CSR & 0.963 & 0.495 & 1.458 & 0.3395 & Partial \\
\hline
\end{tabular}

Dependent variable: OP

\section{Discussion}

The initial outcome of this study revealed that, embarking CSR activities as a company leads to OP. CSR activities contributes more significantly to OP; followed by the mediating role of employees job satisfaction which contribute marginal (see Table-6). The findings of this study is significant because the more organization carryout CSR activities the more employees will be satisfied with their jobs and feels part of the company because of the social programmes the organization is carrying on, this give them motivation to work better to achieve the organizational objective which ultimately result to performance. Secondly, the findings revealed that all hypotheses stated in the study, thus, $\mathrm{H} 1, \mathrm{H} 2$ and $\mathrm{H} 3$ were all accepted and supported by the research findings. 
Hypothesis one (H1); revealed a positive relationship between CSR activities and OP. This findings shows that the more an organization do more of CSR activities, the more the company will perform better in the industry. This is in line with Ghanaweb. com report of $31^{\text {st }}$ October 2017 on Vodafone Ghana emerging as CSR Telecom Company of the year. The Award came on the back of the flagship CSR programmes they embarked on, thus Health line TV show, Instant school and Vodafone Scholar. This CSR activities has made their company performs tremendously over the last few years. A lot of investment were made in CSR activities which lead to the increase of market share in December 2018 by $23.97 \%$ (NCA, 2018).

Hypothesis two (H2), show a positive relationship between CSR activities and employees job satisfaction. This findings shows that the more the organization do more of CSR activities, the more employees will be satisfied with their jobs and continue to stay and work for the organization. When employees sees that their organization partakes in socially responsible activities, they are more likely to be recognize with that organization. Subsequently, this recognition toward their organization tends to translate into satisfaction of their job, which will lead to high levels of job performance.

Hypothesis three (H3), show a positive relationship between ESAT and OP. The findings shows that, the more employees are satisfied with their jobs, the more they will provide a better service to the organization which will lead to good sales and subsequently lead to OP. This is in line with Heskett et al. (1997) suggestion. He explained the concept with the analogy of the satisfaction mirror, that is when employees are satisfied in the company, it will reflect in customer satisfaction and ultimately OP.

\section{Mediating role of ESAT on CSR and OP}

The main objective here is to test the mediating role of ESAT on the relationship between CSR and OP. To achieve the above objective, the researcher first examines the direct effect of CSR activities as a whole on OP. It was not surprising that CSR activities positively and significantly influenced $\mathrm{OP}(\mathrm{p}>0.000)$. This results empirically can therefore be interpreted that, the more companies in Ghana embarks more on CSR activities the more the companies will make a lot of profit. Because in Ghana, Many people believes in charity works. So therefore once the company carry out CSR activities, they tend to buy more from the company because they believe that when the company makes profit, it will channel part of the profit to the development of the community (Gavin and Maynard, 1975). For instance is the case of Vodafone Ghana where they embark on more CSR activities in the communities, this tend to increase their market share in the telecommunication industry. This conclusion is in line with earlier studies (Choi and Yu 2014; Gallardo-Vázquez and Sanchez-Hernandez 2014).

With respect to the mediation effect, the researcher followed the suggestion of Baron and Kenny (1986). From the study, ESAT was found to have partial mediation 
effect on the relationship between CSR activities and OP. with regards to the type of mediation, the results depict that ESAT has partial mediation relationship between CSR activities and OP $(\mathrm{p}<0.000)$. This indicates that CSR activities alone can influence OP even without ESAT. However, motivating employees with all benefit they deserve will increase the ESAT, therefore the need for investment CSR activities so that it will increase OP. Confirming the above results, findings of (Viswesvaran et al., 1998), which indicates that CSR activities on its own help build good corporate image and increase in market share which subsequently will lead to a better OP.

\section{The Influence of ESAT on OP}

The last objective of the paper tends to look at the influence of ESAT on OP. The outcome of the above study depicts that ESAT positively and significantly influence OP $(p<0.000)$. This results could be explained that when employees are highly satisfied with organization's social interventions programmes, they tend to work well because they feel part of the organization (Peterson, 2004). Most workers wants to align themselves with companies that embark on charity work (Skudiene \& Auruskeviciene, 2012). This influence their perception and they tend to work more in order to achieve the organization's objective, which ultimately is OP. This outcome is similar to the findings of earlier scholars like (Barnett, 2007; Chiang, 2010). Secondly the investment on employees thus the internal CSR activities, when an organization takes care of the psychological contract fulfillment, thus improve their salaries, health care and other allowances and bonuses, employees are being motivated to work harder therefore leading to job performance and subsequently OP. This outcome is in line to the findings of earlier studies of (Turker, 2009; Aguilera et al., 2007)

\section{Conclusion and Implications}

This study focused on role of ESAT on the relationship between CSR activities and $\mathrm{OP}$ in some companies in Ghana. Findings with regards to the effect of CSR activities on OP revealed that, companies tend to become more successful when they engage in CSR activities, those companies who consider their employees in their CSR activities (thus intrinsic) tend to provide some level of satisfaction to their employees. The success of an organization depends on the satisfaction of its employees. The higher the employee satisfaction, the more productivity they will become which will lead to the growth of work, and eventually leads to performance of the companies.

Some employees enjoy the extrinsic value of CSR from their companies. These companies tend to create Boreholes, Toilet facilities, Hospitals etc. in the areas where these employees stays or leaves. 
This study also revealed that, CSR Activities also influences ESAT. The findings shws that employees' takes into consideration companies that embark CSR initiatives before they join companies. They tend to be more satisfied with companies who embarks on CSR activities because they feel that those company impact on people's lives. They provide them portable water and other social amenities they need (Gavin and Maynard, 1975). Employees of the companies enjoy from CSR activities, thus the intrinsic aspect of it, thus providing them with better salaries, good retirement packages, and good health care delivery plans.

Finally, the study also revealed that, ESAT influences OP. The findings shows that ESAT plays a pivotal role in fostering OP. When employees are satisfied with their jobs, they tend to give out their best in terms of their performance. Therefore they are able to meet their target and go beyond it. They are able to bring more sales to the company. This is in line with the report by Eugenio Proto of University of Bristol that Google invested substantial amount on the well-being of heir employee which today it is translating into performance for the company. It was also reported by www.usatoday.com that, Google is considered as nearly the universally acclaimed great place to work. Its stock has soared almost about 674\% since its inception in August 2004 therefore Googles performance in that industry is outstanding due to the support of employees (usatoday Report, 2013).

\section{Contribution}

This research contributes to industry and research related areas on Corporate Social Responsibility. Practitioners, professionals and researchers get the opportunity to explore the response of employees with regards to CSR activities. Secondly, at the industry level, the results of the study shows that, companies that embark on CSR activities do satisfy their employees, and ESAT plays a key role when it comes to organizational performance. It is in the best interest of the organization to know how to retain their employees by making them satisfied and motivated in order to achieve an extraordinary outcome. Organizational success depends on how satisfied an employee is the more the employee is satisfied the more it enhance productivity, growth, increases the quality of work and even leads to profitability. 


\section{REFERENCES}

Aguilera, R., V., Rupp, D., E., Williams, C., A., \& Ganapathi, J., (2007).Putting the S back in corporate social responsibility: A multilevel theory of social change in organizations. Academy of management review, 32(3), 836-863.

Barnett, M., L., (2007). Stakeholder influence, capacity and the variability of financial returns to corporate social responsibility. Academy of Management Review, 32(3), 794-816.

Becchetti, L., Ciciretti, R., Hasan, I., \& Kobeissi, N. (2012). Corporate social responsibility and shareholder's value. Journal of Business Research, 65(11), 1628-1635.

Blazovich \& Smith, (2010). Social issues in management research: experts" views, analysis and commentary. Business and Society.

Brammer, S., Millington, A., \& Rayton, B., (2007). The contribution of CSR to organizational commitment. The International Journal of Human Resource Management, 18(10), 1701-1719.

Brown T., J., \& Dacin P., A., (1997). The Company and the product: corporate associations and consumer product responses. Journal of Marketing, 61(1), 68-84.

Brown, S., P., \& Lam, S., K., (2008). A meta-analysis of relationships linking employee satisfaction to customer responses. Journal of Retailing, 84 (3), 243-55.

Chan, K. C., Gee, M. V., \& Steiner, T. L., (2000). Employee happiness and corporate financial performance. Financial Practice and Education, 10, 47-52.

Chandrasekar, K., (2011). Workplace environment and its impact on OP in public sector organizations. International Journal of Enterprise Computing and Business Systems, 1, 1-16.

Chiang, C. C., (2010). How CSR influences employee job satisfaction in the hotel industry. UNLV Theses, Dissertations, Professional Papers, \& Capstones. 598.

Chin, W., (2010). How to write up and report PLS analyses. In C. W. W. EspositoVinzi V, Henseler J, Wang $\mathrm{H}$ (Ed.), Handbook of partial least squares: concepts, methods and applications (pp. 655 - 690). Heidelberg: Springer

Choi, Y., \& Yu, Y. (2014). The influence of perceived corporate sustainability practices on employees and OP. Sustainability, 6(1), 348-364.

Dawson, M. E., \& Abbott, J., (2009). Hospitality culture and climate: Keys to retaining hospitality employees and creating competitive advantage. In International CHRIE Conference-Refereed Track (p. 3).

Ellinger, A. D., Ellinger, A. E., Yang, B., \& Howton, S. W., (2002). The relationship between the learning organization concept and firm's financial performance: An empirical assessment. Human Resource Development Quarterly, 13, 5-22.

Evans, J. R., \& Jack, E. P., (2003). Validating key results linkages in the Baldrige Performance Excellence Model. The Quality Management Journal, 10, 7-24.

Fassin, Y. (2009). The stakeholder model refined. Journal of Business Ethics, 84, 113-135.

Fornell, C., \& Larcker, D. F. (1981a). Evaluating structural equation models with unobservable and Variables and measurement error. Journal of Marketing Research, 18(1), 39-50.

Fornell, C., \& Larcker, D. F. (1981b). Evaluating structural equation models with unobservable and Variables and measurement error. Journal of Marketing Research, 18(1), 39-50.

Fornell, C., (1992). A national customer satisfaction barometer: the Swedish experience. Journal of Marketing, 56, 6-21.

Fornell, C., Mithas, S., Morgenson, F.V., \& Krishnan, M.S., (2006). Customer satisfaction and stock prices: high returns, low risk. Journal of Marketing, 70(1), 114.

Gallardo-Vázquez, D., \& Sanchez-Hernandez, M. I. (2014). Measuring Corporate Social Responsibility for competitive success at a regional level. Journal of Cleaner Production, 72, 14-22. 
Garvin, J. F., \& Maynard, W. S. (1975). Perceptions of Corporate Social Responsibility. Personnel Psychology, 28(3), 377-387

Goslin, P., A., (2005). Managing employee satisfaction of volunteers in South African sport. African Journal for Physical Health Education, 12, 30-40.

Hair, J., Ringle, C. M., \& Sarstedt, M. (2011). PLS-SEM: Indeed a Silver Bullet. Journal of Marketing Theory and Practice, 19(2), 139-151

Harter, J. K., Schmidt, F. L., \& Keyes, C. L. M. (2003), Well-being in the workplace and its relationship to business outcomes, A Review of the Gallup Studies. In Keyes, C. L. M., \& Haidt, J. (Eds). Flourishing: The Positive Person and the Good Life, Chapter 9. (pp. 205-224). Washington D.C: American Psychological Association.

http://www.nhsemployers.org/ /media/Employers/Documents/Retain\%20and\%20improve/Harter\%20et\%20al\%202002\%20WellbeingReview.pdf [accessed on: 07/10/2019]

https://ca.indeed.com/cmp/Mtn-Ghana/reviews [accessed on: 07/10/2019]

https://www.myjoyonline.com/business/2018/november-14th/mtn-adjudged-csr-company-of-the-year. php [accessed on: 07/10/2019]

Hartline, M.D., \& Ferrell, O.C., (1996). The management of customer-contact service employees: an empirical investigation, Journal of Marketing, 60, 52-70.

Huselid, M. A., (1995). The impact of human resource management practices on turnover, productivity, and corporate financial performance. Academy of Management Journal, 38, 635-672.

Joshi et al., (2010). Unpacking generational identities in organizations, Academy of Management Review, 35(3), 392-414.

Judge, T. A., Thoresen, C. J., Bono, J. E., \& Patton, G. K. (2001). The job satisfaction-job performance relationship: A qualitative and quantitative review. Psychological Bulletin, 127, 376-407.

Kassinis, G., \& Vafeas, N. (2006). Stakeholder pressures and environmental performance. Academy of Management Journal, 49, 145-159.

Kang, K. H., Lee, S., \& Huh, C. (2010). Impacts of positive and negative CSR activities on company performance in the hospitality industry. International Journal of Hospitality Management, $29(1), 72-82$.

Khanifar, H., Nazari, K., Emami, M., \& Soltani, H. A. (2012). Impacts CSR activities on company financial performance. Interdisciplinary Journal of Contemporary Research in Business, 3(9), 583-592.

Klein J., \& Dawar, N. (2004). CSR and consumers attributions and brand evaluations in a product harm crisis. International Journal of Research in Marketing, 21, 203-217.

Koh, H.C., \& Boo, E. H. Y (2001). The link between organizational ethics and job satisfaction: a study of managers in Singapore, Journal of Business Ethics, 29, 309-324

Koys, D. J. (2001). The effects of employee satisfaction, organizational citizenship behavior, and turnover on organizational effectiveness: a unit-level, longitudinal study. Personnel Psychology, 54, 101-114.

Latif, M. S., Ahmad, M., Qasim, M., Mushtaq, M., Ferdoos, A., \& Naeem, H. (2015). Impact of ESAT on OP. European Journal of Business and Management, 7, 166-171.

Lee, S., \& Park, S. Y. (2009). Do socially responsible activities help hotels and casinos achieve their financial goals? International Journal of Hospitality Management, 28(1), 105-112.

Lin, Yang, \& Liou, Lin, C. H., Yang, H. L., \& Liou, D. Y. (2009). The impact of CSR on financial performance: Evidence from business in Taiwan. Technology in Society, 31(1), 56-63.

Mafini, C., \& Pooe, D., R., I. (2013). The relationship between employee satisfaction and OP: Evidence from a South African government department. The SA Journal of Industrial Psychology, 39(1). http://www.sajip.co.za/index.php/sajip/article/view/1090/1332

Maignan, I., \& Ferrell, O. C. (2000). Measuring corporate citizenship in two countries: The case of the United States and France. Journal of Business Ethics, 23, 283-297. 
Maignan, I., Ferrell, O. C., \& Hult, G. T. M. (1999). Corporate citizenship: cultural antecedents and business benefits. Journal of the Academy of Marketing Science, 27, 455-469.

Maignan, I., Ferrell, O.C., \& Ferrell, L. (2005). A stakeholder model for implementing social responsibility in marketing. European Journal of Marketing, 39 (9/10), 956-977.

Maron, I.Y.,(2006). Toward a Unified Theory of the CSP - CFP link. Journal Business Ethics 67(2), $191-200$.

McWilliams, A., \& Siegel, D. (2001). Corporate Social Responsibility: A theory of the firm perspective. The Academy of Management Review, 26(1), 117-127.

Meyer, J., \& Allen, N., (1997). Commitment in the Workplace: Theory, Research, and Application, Sage Publications.

Messick, S. (1988). Validity. In R. L. Linn (Ed.), Educational Measurement (3rd ed.). New York, NY.: Macmillan.

Miah M., M., (2018) .The impact of employee job satisfaction toward OP: A study of private sector employees in Kuching, East Malaysia, International Journal of Scientific and Research Publications, 8(12), 270-278.

Muhammad, S., Latif, M., A., Muhammad Q., M., M., Amber F., H., N., (2013). Impact of ESAT on OP, European Journal of Business and Management, 5(5), 166-171.

Orlitzky, M., Schmidt, F. L., and Rynes, S.L., (2003). Corporate Social and Financial Performance: A Meta-Analysis. Organization Studies, 24(3), 403- 441.

Ostroff, C. (1992). The relationship between satisfaction, attitudes, and performance: An organizational level analysis. Journal of Applied Psychology, 77, 963-974.

Özdamar, K. (2017).Olcek ve test gelistirme yapisal esitlik modellemesi IBM SPSS, IBM SPSS AMOS ve MINTAB uygulamali. [Scale and test development Structural equation modeling IBM SPSS, IBM SPSS AMOS and MINTAB applied].Eskisehir: Nisan Kitabevi

Preston, L., \& O‘Bannon, D., (1997).The corporate social-financial performance relationship, Business \& Society, 36(4), 419.

Raihan T., R., Karim (2017). CSR and employee job satisfaction: A case from MNCs Bangladesh, Global Journal of Human Resource Management, 5(3), Pp.26-39, available at: https://www. researchgate.net/publication/315706137_CSR_AND_EMPLOYEE_JOB_SATISFACTION_A_CASE_FROM_MNCS_BANGLADESH/citations [Accessed on: 05/10/19]

Ringle, C.M., Wende, S, \& Becker, J.M. (Producer) (2015). SmartPLS 3. Retrieved from http://www. smartpls.com.

Rodgers, W., choy, H.L., Guiral, A., (2013). Do Investors Value a firm's commitment to social activities? Journal of Business Ethics, 114(4), 607 - 623.

Rodrigo, P., \& Arenas, D., (2008). Do Employees Care About CSR Programs? A Typology of Employees According to their Attitudes. Journal of Business Ethics, 83(2), 265-283.

Saeidi, S. P., Sofian, S., Saeidi, P., Saeidi, S. P., \& Saaeidi, S. A. (2015). How does CSR contribute to firm financial performance? The mediating role of competitive advantage, reputation, and customer satisfaction. Journal of Business Research, 68(2), 341-350.

Schneider, B., Hanges, P. J., Smith, D. B., \& Salvaggio, A., N. (2003). Which comes first: Employee attitudes or organizational financial and market performance? Journal of Applied Psychology, $88,836-851$.

Skudiene, V., \& Auruskeviciene, V., (2012). The contribution of CSR to internal employee motivation. Baltic Journal of Management, 7(1), 49-67.

Swaen, V., \& Chumpitaz, R. C. (2008). Impact of CSR on consumer trust. Recherche et Applications en Marketing, 23(4), 7-33.

Tsoutsoura, M. (n.d.). CSR and Financial Performance. Retrieved from eScholarship: http://escholarship.org/uc/item/111799p2[accessed on: 05/10/19] 
Turker, D. (2009). Measuring corporate social responsibility: a scale development study. Journal of Business Ethics, 85(4), 411-427. http://dx.doi.org/10.1007/s10551-008-9780-6.

Tziner, A., Oren, L., Bar, Y., \& Kadosh, G. (2011). Corporate social responsibility, organizational justice and job satisfaction: How do they interrelate, if at all? Revista de Psicología del Trabajo y de las Organizaciones, 27, 67-72.

Uadiale, O. M., \& Fagbemi, T., O., (2012). CSR and Financial Performance in Developing Economies: The Nigerian Experience. Journal of Economics and Sustainable Development, 3(4), 4454.

Usakli, A., \& Baloglu, S. (2011). Brand personality of tourist destinations: An application of self-congruity theory. Tourism Management, 32(1), 114-127.

Valentine, S., \& Barnett, T. (2003). Ethics code awareness, perceived ethical values, and organizational commitment, Journal of Personal Selling and Sales Management, 23, 359- 367.

Valentine, S., \& Fleischman, G. (2008). Ethics Programs, Perceived CSR and Job Satisfaction, Journal of Business Ethics, 77(2), 159-172.

Viswesvaran, C., S. P. Deshpande and J. Joseph (1998), Job Satisfaction as a Function of Top Management Support for Ethical Behavior: A Study of Indian Managers', Journal of Business Ethics $17,365-371$

Waddock, S., A., \& Graves, S., B., (1997). The Corporate Social Performance-Financial Performance Link. Strategic Management Journal, 18(4), 303-319

Welford, R., (2004). CSRin Europe and Asia: Critical Elements and Best Practice. Journal of Corporate Citizenship, 13(1), 31-47.

Maron, 2006, S. R., Dahiyat, D. A., Awwad, M. A., \& Hajjat, E. S., (2012). The Impact of Adopting CSR on Corporate Financial Performance: Evidence from Jordanian Banks. Interdisciplinary Journal of Contemporary Research in Business, 4(5), 34-44.

Wright, T. A., \& Cropanzano, R. (2000). Psychological well-being and job satisfaction as predictors of job performance. Journal of Occupational Health Psychology, 5, 84-94.

Wu, M.L., (2006). Corporate social performance, corporate financial performance, and firm size: a meta-Analysis. J.Am.Acad.Bus. 8(1), 163 -171.

Yang, F., J., Lin, C., W., \& Chang, Y., N., (2010). The linkage between corporate social performance and corporate financial performance. African Journal of Business Management, 4(4), 406-413.

Zohir, S., C. (2007). Role of Dhaka export processing zone: Employment and empowerment. Research Report, Bangladesh Institute of Development Studies, Dhaka, People's Republic of Bangladesh. 